\title{
PENGENAAN PAJAK PERTAMBAHAN NILAI TERHADAP JASA PENYELENGGARAAN SEMINAR
}

\author{
Rian Faishal Arkhan'); Wahyu Widodo Rodhiyawan ${ }^{2)}$ \\ 1) rian.arkhan@gmail.com, Direktorat Jenderal Pajak \\ 2)rdw.wahyu@gmail.com*, Direktorat Jenderal Pajak
}

\begin{abstract}
The purpose of this study is to explain the scope of educational services in value added tax, identify whether the seminars held by BeBrightEvent and the Mechanical Student Association (HMM) include taxable services, understand the events of organizing seminars, understand the classification of entrepreneurs and Taxable Entrepreneurs, and identify the imposition of Value Added Tax on seminar organizing services by BeBrightEvent and HMM. The research method uses descriptive qualitative. Education services are services for providing school education and services for providing education outside of school. Services for organizing seminars are not services included in the educational services group, but services included in the company and trade services group in the form of management services, unless organized by educational institutions both government and private. Anyone who delivers taxable goods and/or taxable services in the context of his business activities is an entrepreneur who can be confirmed as a taxable entrepreneur.
\end{abstract}

Keywords: Education services, Value added tax, Seminar

\begin{abstract}
Abstrak
Tujuan penelitian ini adalah untuk menjelaskan ruang lingkup dari jasa pendidikan dalam pajak pertambahan nilai, mengidentifikasi apakah seminar yang diselenggarakan BeBrightEvent dan Himpunan Mahasiswa Mesin (HMM) termasuk jasa kena pajak, memahami peristiwa penyelenggaraan seminar, memahami pengklasifikasian pengusaha dan Pengusaha Kena Pajak, dan mengidentifikasi pengenaan Pajak Pertambahan Nilai terhadap jasa penyelenggaraan seminar oleh BeBrightEvent dan HMM. Metode penelitian menggunakan kualitatif deskriptif. Jasa pendidikan adalah jasa penyelenggaraan pendidikan sekolah dan jasa penyelenggaraan pendidikan luar sekolah. Jasa atas penyelenggaraan seminar bukanlah jasa yang masuk dalam kelompok jasa pendidikan, melainkan jasa yang termasuk kedalam kelompok jasa perusahaan dan perdagangan yang berupa jasa pengelolaan, kecuali diselenggarakan oleh lembaga pendidikan baik milik pemerintah maupun swasta. Siapapun yang menyerahkan barang kena pajak dan/atau jasa kena pajak dalam rangka kegiatan usahanya maka termasuk pengusaha yang bisa dikukuhkan sebagai pengusaha kena pajak.
\end{abstract}

Kata kunci : Jasa pendidikan, Pajak pertambahan nilai, Seminar,

\section{PENDAHULUAN}

Pajak Pertambahan Nilai atau PPN merupakan pajak atas konsumsi yang diterapkan di Indonesia. PPN merupakan pajak objektif yang berarti PPN dikenakan berdasarkan apa yang diserahkan bukan kepada siapa diserahkan. PPN sendiri hanya mengenal tarif tunggal, yaitu $10 \%$ dari harga barang dan dikenakan terhadap setiap level distribusi namun tidak bersifat komulatif. Hal ini berarti PPN yang dibayarkan dapat dikreditkan oleh produsen atau distributor selama memenuhi persyaratan yang berlaku dan penanggung sebenarnya dari PPN adalah konsumen akhir.

PPN bersifat pajak tidak langsung, yang berarti PPN dibayarkan kepada kas negara oleh penjual yang berasal dari uang yang dipungut dari pembeli, namun pembeli juga dapat menyetorkan sendiri PPN ke kas negara jika undang-undang menyatakan demikian. PPN menggunakan indirect substraction method yang berarti PPN menggunakan metode pengkreditan pajak masukan terhadap pajak keluaran. Seperti dari arti namanya, pajak pertambahan nilai merupakan pajak yang dikenakan atas setiap nilai tambah dari suatu barang. PPN dikenakan atas penyerahan barang dan/atau jasa, namun tidak semua penyerahan barang dan/atau jasa dikenakan PPN, karena PPN mengenal adanya objek dan bukan objek pajak, selain objek dan non objek juga terdapat fasilitas dalam PPN seperti PPN dibebaskan, PPN tidak dipungut dan juga tarif pajak 0\% (nol persen). Sehingga atas penyerahan barang dan/atau jasa yang bukan merupakan objek PPN tidak dikenakan PPN atau dikecualikan dari PPN. 


\section{EDUCORETAX}

Volume 1 No. 2, Juni 2021

Berdasarkan Undang-Undang Republik Indonesia Nomor 42 Tahun 2009 tentang Perubahan Ketiga atas Undang-undang Nomor 8 Tahun 1983 tentang Pajak Pertambahan Nilai Barang dan Jasa Dan Pajak Penjualan Atas Barang Mewah, di Indonesia, pemberlakuan bukan objek PPN dikenakan terhadap empat macam barang dan tujuh belas macam jasa.

Dari ke tujuh belas kelompok jasa yang bukan merupakan objek PPN tersebut, salah satunya adalah jasa pendidikan. Jasa yang masuk dalam pengertian jasa pendidikan dapat berupa jasa penyelenggaraan sekolah baik formal maupun nonformal. Dalam kelompok jasa pendidikan, terdapat sebuah jasa yang cukup membingungkan apakah atas penyerahan jasa tersebut termasuk ke dalam pengertian jasa pendidikan atau bukan, yaitu jasa atas penyelenggaraan seminar.

Yang dimaksudkan dengan membingungkan adalah seminar menurut Surat Direktur Jendral Pajak Nomor S-210/PJ.32/1991 Tentang PPN atas Jasa Penyelenggaraan Seminar pada angka 2 , bukanlah jasa yang masuk dalam pengertian jasa pendidikan, melainkan termasuk dalam kategori jasa perusahaan dan perdagangan. Sehingga jasa atas penyelenggaraan seminar akan masuk ke dalam kelompok jasa perusahaan dan perdagangan seperti jasa pengelolaan, maka atas penyelenggaraan seminar akan terutang PPN. Namun, proses dari penyelenggaraan seminar pada umumnya terdapat transfer ilmu atau pembelajaran dari narasumber kepada peserta seminar yang merupakan suatu proses pendidikan. Dari uraian tersebut, penulis merasa tertarik untuk membahas tentang jasa penyelenggaraan seminar yang bukan merupakan bagian dari jasa pendidikan, namun pada proses kegiatan seminar terjadi transfer ilmu dari narasumber kepada peserta.

Jasa penyelenggaraan seminar menurut Surat Direktur Jendral Pajak Nomor S210/PJ.32/1991 Tentang PPN atas Jasa Penyelenggaraan Seminar dapat dibedakan menjadi dua berdasarkan siapa yang menyelenggarakan seminar tersebut. Dalam hal ini, pihak penyelenggara yang dimaksud adalah lembaga pendidikan dan bukan lembaga pendidikan. Penelitian ini menyajikan data dan fakta berupa penyelenggaraan seminar yang dilakukan oleh lembaga pendidikan yaitu seminar nasional yang masuk dalam rangkaian Mechanical Education Fair yang diselenggarakan oleh Himpunan Mahasiswa Mesin Universitas Diponegoro dan juga seminar yang diselenggarakan oleh bukan lembaga pendidikan yaitu penyelenggaraan seminar oleh BeBrightEvent.

Mechanical Education Fair atau yang bisa disebut dengan MEF merupakan serangkaian acara tahunan tentang Pendidikan yang diselenggarakan oleh Himpunan Mahasiswa Mesin (HMM) Universitas Diponegoro (UNDIP). HMM sendiri merupakan himpunan mahasiswa yang berada di bawah pengawasan Jurusan Teknik Mesin UNDIP. MEF yang diselenggarakan oleh HMM terdiri dari beberapa rangkaian acara di bidang pendidikan seperti Lomba Karta Tulis Ilmiah atau LKTI dan diikuti acara puncak berupa seminar nasional.

Yang dimaksud dengan seminar nasional adalah sebuah seminar yang memiliki topik bahasan yang berskala nasional atau bisa juga diartikan dengan seminar yang dengan bahasan utama seputar permasalahan di ruang lingkup nasional. Acara LKTI yang termasuk dalam rangkaian acara MEF merupakan lomba karya tulis ilmiah yang bisa diikuti oleh semua mahasiswa di Indonesia yang tentunya dengan tema yang telah ditentukan. Sedangkan untuk acara seminar nasional yang menjadi acara puncak dari MEF itu sendiri dapat diikuti oleh semua lapisan masyarakat atau bersifat umum.

Proses pelaksanaan dari Seminar Nasional pada tahun 2017 dengan tema "Indonesia Emas 2045: Saatnya Pemuda Berkarya" yang diselenggarakan oleh HMM merupakan seminar yang menghadirkan Menteri ESDM periode 2011-2014 yaitu Dahlan Iskan dan Chief Engineer pesawat N219 dari PT Dirgantara Indonesia yaitu Palmana Banandhi. Seminar ini membahas tentang peluang dan kesempatan generasi masa kini mengenai perannya dalam perkembangan 


\section{EDUCORETAX}

Volume 1 No. 2, Juni 2021

Indonesia di tahun 2045 terutama pada sektor infrastruktur dan juga industri melalui pembentukan serta pengembangan sember daya manusia yang terbaik.

Seminar yang diadakan oleh HMM ini dapat dikatakan sebagai proses pengadaan seminar secara langsung. Yang dimaksud dengan secara langsung adalah, penyelenggaraan seminar tersebut ditangani langsung oleh HMM tanpa menggunakan jasa perantara dari pihak ke tiga atau bisa disebut dengan jasa event organizer. HMM yang selaku penyelenggara menghububungi pembicara untuk bekerjasama dengan pembicara untuk menjadi narasumber dalam Seminar Nasional dengan imbalan sesuai dengan kesepakatan. HMM selaku penyelenggara juga bertugas atas semua teknis penyelenggaraan hingga ke pemasaran dan penjualan tiket.

BeBrightEvent merupakan sebuah usaha milik perorangan yang belum berbadan hukum berupa Training Provider dan Event Organizer yang bergerak di bidang Seminar, Pelatihan dan In House Training (IHT). Dengan visi untuk membantu lebih banyak orang demi mempersiapkan dirinya demi menghadapi masa depan yang lebih baik, BeBrightEvent mempunyai Misi untuk mewujudkan Visi tersebut melalui peningkatan karakter dan sikap pribadi, percepatan menuju sukses dan pengembangan sumber daya manusia. Dalam setiap kegiatan, BeBrightEvent juga mendorong terbentuknya komunitas bagi para peserta sebagai wadah menyatukan individu yang ingin menjadi lebih baik dalam mewujudkan mimpi mereka.

Bebrightevent didirikan oleh Muhammad Yunandar dan ketiga rekannya pada tanggal 27 Mei 2014 dengan misi utama membantu setiap individu dalam peningkatan karakter serta sikap dan mengembangkan proses bisnis dan usahanya menjadi lebih sukses melalui Workshop dan Training. Fokus dari BeBrightEvent hingga saat ini adalah pemasaran bisnis melalui media daring, karena di era sekarang yang sudah serba berbasis teknologi ini, pemasaran menggunakan media daring merupakan terobosan media berpromosi yang paling simpel, hemat biaya dan dapat menjadi kunci kesuksesan dalam suatu bisnis atau produk karena media daring tidak mengenal batasan ruang dan waktu. Dengan semakin banyaknya minat serta permintaan terhadap seminar maupun pelatihan, BeBrightEvent sudah berkembang cukup cepat dari keadaan semula. Training Provider dan Event Organizer sudah memiliki pasar yang sudah cukup luas walau hanya mengandalkan pemasaran melalui media elektronik.

Sebagai training provider dan event organizer, dalam setiap proses menjalankan kegiatan usahanya baik seminar, workshop training maupun in house training, BeBrightEvent berperan dalam membantu merencanakan, mempersiapkan, menjalankan, dan mempromosikan melalui pelatihan, training, workshop atau seminar untuk pengembangan, pertumbuhan sumberdaya manusia. Yang dimaksudkan dengan membantu adalah, BeBrightEvent dalam menjalankan kegiatannya bukan berdasarkan keinginan sendiri, melainkan penyelenggaraan tersebut berdasarkan permintaan klien atau berdasarkan kerjasama dengan pihak lain. Berdasarkan uraian tersebut, ini berarti proses penyelenggaraan akan seminar yang diselenggarakan oleh BeBrightEvent tersebut merupakan permintaan dari klien atau hasil kerjasama dengan pihak lain.

Dalam proses penyelenggaraan seminar tersebut, BeBrightEvent yang sebagai event organizer memiliki peran dari mulai perencanaan hingga pemasaran atas penyelenggaran seminar. Sebagai contoh, ada sebuah organisasi yang ingin menyelenggarakan seminar tentang suatu topik, namun karena keterbatasan pengetahuan tentang seminar, tenaga dan, waktu, maka organisasi tersebut meminta bantuan dan menyerahkan semua teknis kepada BeBrightEvent. BeBrightEvent bertugas penuh dalam penyelenggaran seminar hingga mencari pembicara yang tepat untuk seminar tersebut.

Penelitian terdahulu terkait tema pajak pertambahan nilai terhadap seminar ini beluum dijumpai dalam berbagai aplikasi penelusuran publikasi karya ilmiah. Penelitian terdahulu yang mendekati tema penelitian adalah Pratiwi (2014) yang menjelaskan mengenai strategi 


\section{EDUCORETAX}

Volume 1 No. 2, Juni 2021

peningkatan Pendapatan Asli Daerah (PAD), investasi dan pertumbuhan ekonomi kota Semarang melalui MICE (Meeting, Incentive, Convention dan Exhibition). Yang juga sangat berbeda jika dikatikan dengan pajak pertambahan nilai. Dengan demikian, posisi penelitian merupakan suatu kebaharuan tersendiri dalam menganalisis pajak pertambahan nilai atas jasa seminar.

Tujuan penelitian ini adalah untuk menjelaskan ruang lingkup dari jasa pendidikan dalam PPN, mengidentifikasi apakah seminar yang diselenggarakan BeBrightEvent dan HMM termasuk jasa kena pajak, memahami peristiwa penyelenggaraan seminar oleh BeBrightEvent dan HMM, memahami apakah BeBrightEvent dan HMM termasuk dalam pengertian pengusaha kena pajak, dan mengidentifikasi pengenaan pajak pertambahan nilai terhadap jasa penyelenggaraan seminar oleh BeBrightEvent dan HMM.

\section{KAJIAN PUSTAKA \\ Pajak Pertambahan Nilai}

PPN menurut Thuronyi (2003, dalam Azizah \& Wijaya, 2020) adalah pajak transaksi yang dipungut pada semua tahap produksi dan distribusi. Pajak ini dikenakan atas transaksi barang dan jasa. Transaksi yang dikenakan pajak adalah pengadaan barang dan jasa yang diatur dalam peraturan perundang-undangan. Barang yang dimaksud adalah barang berwujud, kecuali tanah dan uang. Sedangkan jasa yang dikenakan PPN tidak dapat ditentukan secara pasti dan menyeluruh. Pajak pertambahan nilai menurut Pohan (2016, dalam Wijaya \& Nirvana, 2021) pada hakikatnya merupakan beban konsumen akhir karena mengonsumsi barang atau jasa yang menjadi objek pajak, yang tanggung jawabnya digeser ke pihak lain, dalam hal ini pengusaha kena pajak. Adapun English (dalam Wijaya \& Sabrina, 2021) mendefinisikan PPN sebagai pajak universal atas kegiatan konsumsi, yang merupakan pajak tidak langsung yang dibebankan oleh tiap konsumen atas transaksi barang kena pajak ataupun jasa kena pajak tertentu.

\section{Seminar}

Seminar menurut Ahmadi (1988) merupakan kegiatan yang dilakukan sebagai proses untuk memecahkan suatu masalah, atau proses menemukan solusi yang biasanya diangkat dari hasil sebuah penelitian atau literatur. Seminar pada umumnya diselenggarakan dengan pembahasan sebuah topik tertentu tentang sebuah permasalahan yang ada. Proses berjalannya sebuah seminar dipimpin oleh seorang moderator yang sekaligus berperan sebagai time keeper dalam sebuah seminar, sehingga apa yang disampaikan oleh narasumber tetap sesuai dengan topik yang dibahas dan tepat waktu sesuai dengan rangkaian acara. Seminar seringkali diselenggarakan melalui dialog atau sebuah presentasi. Pada proses berlangsungnya seminar, pada umumnya seminar tersebut dibuat dengan desain komunikasi dua arah, sehingga peserta seminar diharapkan ikut aktif dalam kegiatan seminar.

Seminar dalam perijinan kegiatan usaha termasuk ke dalam jenis MICE (Meeting, Incentive, Convention dan Exhibition). Pendit (1999) menjelaskan bahwa MICE merupakan wisata konvensi yang mempunyai batasan usaha jasa konvensi, perjalanan insentif, dan pameran merupakan usaha yang memberi pelayanan bagi pertemuan untuk membahas suatu masalah. Adapun Kesrul (2004) menjelaskan Conference atau konferensi sebagai suatu pertemuan yang diselenggarakan terutama mengenai bentuk tata karena, adat atau kebiasaan yang berdasarkan mufakat umum, dua perjanjian antara negara-negara para penguasa pemerintahan atau perjanjian international mengenai topik tawanan perang dan sebagainya.

Seminar dapat dibedakan pada pihak penyelenggara. Seperti menurut Surat Direktur Jendral Pajak Nomor S - 210/PJ.32/1991 tentang PPN atas Jasa Penyelenggaraan Seminar, disini penyelenggaraan seminar dibedakan berdasarkan siapa yang menyelenggarakan seminar 
tersebut. Pihak penyelenggara semiar yang dimaksud adalah Lembaga Pendidikan dan bukan Lembaga Pendidikan.

\section{METODE}

Metode penelitian yang digunakan adalah kualitatif deskriptif. Firdaus (dalam Wijaya \& Mahatma, 2017) menjelaskan bahwa metode deskriptif digunakan untuk meneliti status suatu objek (dapat berupa manusia, peristiwa, dll). Metode deskriptif mempelajari masalah-masalah masyarakat serta situasi-situasi tertentu. Penelitian menggunakan studi literatur, dengan cara mempelajari dan menghimpun data-data atau sumber yang berkaitan terhadap topik bahasan yang diangkat melalui sejumlah literatur yang dapat berupa undang-undang, kajian pustaka, buku, jurnal, berita di media masa dan lainnya. Pengumpulan data dilakukan dengan cara mengumpulkan data yang berhubungan dengan objek penelitian baik berupa wawancara maupun pengambilan data secara langsung pada objek yang dituju.

\section{HASIL DAN PEMBAHASAN}

\section{Ruang lingkup Jasa Pendidikan}

Pengertian jasa menurut Philip Kotler dalam Lupiyoadi, Rambat, dan A. Hamdani, (2011) merupakan setiap aktifitas, manfaat atau performance yang ditawarkan oleh satu pihak ke pihak lain yang bersifat intangible dan tidak menyebabkan perpindahan kepemilikan apapun dimana dalam produksinya dapat terikat maupun tidak dengan produk fisik. Sedangkan pengertian jasa menurut Kamus Besar Bahasa Indonesia adalah perbuatan yang baik atau berguna dan bernilai bagi orang lain, negara, instansi, dan sebagainya. Dengan begitu, jasa dapat diartikan sebagi suatu layanan yang diberikan suatu pihak kepada pihak lain tanpa adanya perpindahan hak kepemilikan. Pengertian dari pendikan menurut Ki Hajar Dewantara (1994) adalah suatu tuntutan di dalam hidup tumbuhnya anak-anak, adapun maksudnya, pendidikan yaitu menuntun segala kekuatan kodrat yang ada pada anak-anak itu, agar mereka sebagai manusia dan sebagai anggota masyarakat dapatlah mencapai keselamatan dan kebahagiaan setinggi-tingginya.

Dalam hubungannya dengan PPN, Jasa Pendidikan termasuk ke dalam kelompok jasa yang diatur dalam pasal 4A ayat 3 Undang Undang Republik Indonesia Nomor 42 Tahun 2009 tentang Perubahan Ketiga atas Undang Undang Nomor 8 Tahun 1983 tentang Pajak Pertambahan Nilai Barang dan jasa dan Pajak Penjualan atas Barang Mewah, yaitu jasa yang tidak dikenai Pajak Pertambahan Nilai. Kelompok penyerahan jasa yang termasuk ke dalam kelompok jasa pendidikan dikelompokkan dapat lagi menjadi dua jenis Jasa Pendidikan yaitu jasa penyelenggaraan pendidikan sekolah dan jasa penyelenggaraan pendidikan sekolah.

a. Jasa Penyelenggaraan Pendidikan Sekolah

Pendidikan sekolah merupakan jenis pendidikan formal. Pendidikan formal sendiri menurut Kamus Besar Bahasa Indonesia merupakan segenap bentuk pendidikan atau pelatihan yang diberikan secara terorganisasi dan berjenjang, baik yang bersifat umum maupun yang bersifat khusus. Penyelenggaraan pendidikan sekolah atau pendidikan formal sendiri terdiri dari beberepa macam jasa penyelenggaraan seperti (1) Jasa Penyelenggaraan Pendidikan Umum, yaitu pendidikan yang ditujukan untuk mengembangakan keterampilan dan standard dasar dalam kehidupan di masyarakat, pendidikan umum tidak diarahkan kepada suatu keterampilan khusus. (2) Jasa Penyelenggaraan Pendidikan Kejuruan, yang merupakan pendidikan yang diselenggarakan demi memberikan suatu keterampilan khusus. Pendidikan kejuruan ini biasanya menghasilkan seseorang yang siap untuk masuk di dalam dunia kerja sesuai keterampilannya. (3) Jasa Penyelenggaraan Pendidikan Khusus atau pendidikan luar biasa yaitu pendidikan yang diselenggarakan khusus untuk orang-orang dengan kebutuhan khusus seperti penyandang kelainan fisik mauun kelainan mental. Mereka yang membutuhkan penanganan 


\section{EDUCORETAX}

Volume 1 No. 2, Juni 2021

khusus ini maka diselenggarakan jasa penyelenggaraan pendidikan khusus. (4) Jasa Penyelenggaraan Pendidikan Kedinasan, yang merupakan pendidikan yang ditujukan untuk membentuk orang-orang yang akan bertugas di instansi pemerintah. Pendidikan kedinasan juga dibentuk untuk menjalankan tugas kedinasan. (5) Jasa Penyelenggaraan Pendidikan Keagamaan, yang merupakan pendidikan yang diselenggarakan guna memberikan pengetahuan lebih lanjut tentang agama. (6) Jasa Penyelenggaraan Pendidikan Akademik, yang merupakan pendidikan yang diselenggarakan guna memperdalam tentang bidang dalam ilmu pendidikan seperti ilmu tentang, alam matematika, ilmu sosial. (7) Jasa Penyelenggaraan Pendidikan Profesional, yang merupakan pendidikan yang ditujukan untuk membentuk tenaga profesional pada keahlian tertentu.

b. Jasa Penyelenggaraan Pendidikan Luar Sekolah

Pengertian pendidikan luar sekolah atau pendidikan nonformal menurut Philip $\mathrm{H}$. Coombs dalam Joesoef, (1992) merupakan semua kegiatan pendidikan yang terorganisasi, sistematis dan dilaksanakan di luar sistem pendidikan formal, yang menghasilkan tipe-tipe belajar yang dikehendaki oleh kelompok orang dewasa maupun anak-anak. Sedangkan pengertian pendidikan luar sekolah menurut Kamus Besar Bahasa Indonesia adalah segenap bentuk pelatihan yang diberikan secara terorganisasi di luar pendidikan formal, misalnya kursus keterampilan.

Dari kedua arti pendidikan luar sekolah seperti hal yang telah diuraikan diatas, pendidikan luar sekolah dapat diartikan dengan semua kegiatan pendidikan nonformal yang diselenggarakan dengan tujuan pembelajaran yang dikehendaki. Pendidikan nonformal ini dapat berupa (1) Lembaga Kursus dan Pelatihan, yang merupakan proses pendidikan akan suatu keahlian atau keterampilan yang dilakukan dalam waktu yang singkat. (2) Kelompok Belajar, yang merupakan suatu bentuk pendidikan nonformal namun diselenggarakan sebagai ganti dari pendidikan formal. Kelompok belajar ini biasanya terdapat di daerah yang masih sulit dijangkau atau diselenggarakan untuk kelompok orang yang kurang mampu secara ekonomi. (3) Taman Kanak-kanak dan Kelompok Bermain, yang merupakan pendidikan nonformal yang diberikan kepada anak dengan usia di bawah usia sekolah. Pendidikan anak ini dimaksudkan untuk membuat anak-anak untuk siap melanjutkan pendidikan dasar atau masuk ke dalam sekolah. (4) Sanggar, yang merupakan tempat yang didirikan khusus sebagai tempat pelatihan kegiatan seni dan budaya. (5) Seminar, yang merupakan sebuah forum pembahasan suatu masalah baik berupa dialog maupun presentasi. Dalam sebuah seminar akan dibahas mengenai suatu masalah dengan para ahli dalam bidang tersebut. Seminar yang termasuk ke dalam kelompok jasa pendidikan berdasarkan angka 3 pada Surat Direktur Jenderal Pajak Nomor S - 210/PJ.32/1991 Tentang PPN atas Jasa Penyelenggaraan Seminar adalah seminar yang diselenggarakan oleh Lembaga pendidikan baik pemerintah maupun swasta, sepanjang seminar yang diadakan masih dalam disiplin ilmu/pendidikan yang dikelolanya.

\section{Penyelenggaraan seminar sebagai Jasa Kena Pajak}

Seminar yang diadakan oleh Himpunan Mahasiswa Mesin Universitas Diponegoro yang masih termasuk dalam rangkaian Mechanical Education Fair ini merupakan bentuk seminar yang dapat masuk dalam kelompok jasa pendidikan seperti yang diatur dalam Pasal 4A ayat (3) huruf g Undang Undang Republik Indonesia Nomor 42 Tahun 2009 tentang Perubahan Ketiga atas Undang Undang Nomor 8 Tahun 1983 tentang Pajak Pertambahan Nilai Barang dan Jasa dan Pajak Penjualan atas Barang Mewah. Hal tersebut diperkuat dengan Surat Direktur Jenderal Pajak Nomor S - 210/PJ.32/1991 Tentang PPN atas Jasa Penyelenggaraan Seminar angka 3 yang menerangkan bahwa seminar yang diselenggarakan oleh lembaga pendidikan baik pemerintah atau swasta, sepanjang seminar yang diselenggarakan tersebut masih dalam disiplin ilmu/pendidikan yang dikelolanya, maka atas penyelenggaraan seminar tersebut tidak kena 
PPN. Hal ini berarti bahwa seminar yang diselenggarakan oleh lembaga pendidikan merupakan penyerahan jasa pendidikan.

Himpunan Mahasiswa Mesin Universitas Diponegoro merupakan organisasi mahasiswa yang berada di bawah Jurusan Teknik Mesin Universitas Diponegoro, sehingga masih dapat dikatakan sebagai lembaga pendidikan. Sehingga proses penyelenggaraan seminar oleh Himpunan Mahasiswa Mesin Universitas Diponegoro tersebut dapat masuk dalam kelompok jasa pendidikan. Sehingga atas uraian diatas, proses penyelenggaraan seminar tersebut tidak kena PPN.

Namun dalam proses penyelenggaraan seminar tersebut, Himpunan Mahasiswa Mesin Universitas Diponegoro hanya bertindak sebagai penyelenggara seminar tetap kena PPN. Hal ini dikarenakan jasa yang diserahkan oleh Himpunan Mahsaiswa Mesin Universitas Diponegoro atas penyelenggaraan seminar tersebut bukanlah merupakan jasa pendidikan, melainkan jasa pengelolan. Di dalam kasus tersebut, pihak yang melakukan penyerahan jasa pendidikan adalah pembicara seminar, hal ini dikarenakan pembicara seminar dan penyelenggara seminar bukanlah satu pihak, tetapi merupakan pihak yang berbeda. Sehingga dalam proses penyelenggaraan seminar tersebut, pihak pembicara lah yang melakukan penyerahan jasa pendidikan, sedangkan pihak penyelenggara hanya melakukan jasa pengelolaan atas penyelenggaraan seminar. Sehingga atas penyelenggraan seminar yang diadakan oleh HMM merupakan Jasa Kena Pajak.

Proses penyelenggaraan seminar yang diadakan oleh BeBrightEvent menurut Surat Direktur Jenderal Pajak Nomor S - 210/PJ.32/1991 Tentang PPN atas Jasa Penyelenggaraan Seminar pada angka 2, yang berbunyi bahwa jasa penyelenggaraan seminar bukan jasa pendidikan sebagaimana di maksud dalam Pasal 1 angka 2 huruf f Peraturan Pemerintah Nomor 2 Tahun 1988 tetapi termasuk dalam kategori jasa perusahaan dan perdagangan yang antara lain meliputi jasa penterjemahan, jasa stenografi, jasa pelaporan persidangan dan sebagainya.

Berdasarkan hal tersebut, atas penyerahan jasa penyelenggaraan seminar oleh perusahaan-perusahaan atau badan tertentu terutang PPN. Hal tersebut juga diperkuat dengan Surat Direktur Jenderal Pajak Nomor S - 359/PJ.313/1999 Tentang PPN dan PPh Atas Jasa Training dan Seminar yang pada poin 3.3 berbunyi bahwa jasa penyelenggaraan seminar adalah bukan jasa pendidikan, oleh karena itu atas penyerahan jasa penyelenggaraan seminar oleh perusahaan/badan tertentu terutang PPN. Namun dalam hal lembaga pendidikan baik pemerintah maupun swasta menyelenggarakan seminar masih dalam rangka disiplin ilmu/pendidikan yang dikelolanya, maka atas penyerahan jasa seminar oleh lembaga pendidikan tersebut tidak terutang PPN.

Berdasarkan dari uraian diatas, proses penyelenggaraan seminar oleh BeBrightEven merupakan penyerahan jasa yang masuk ke dalam objek pajak. Hal ini dikarenakan BeBrightEvent sendiri bukan merupakan lembaga pendidikan, melainkan sebuah badan yang memiliki kegiatan utama yaitu event organizer dan training provider. Dari hal tersebut, atas penyerahan jasa berupa seminar maupun training yang dilakukan oleh BeBrightEvent yang bukan berupa jasa pendidikan, melainkan jasa pengelolaan yang penyerahannya kena PPN.

\section{Peristiwa penyelenggaraan seminar BeBrightEvent dan HMM UNDIP}

Berdasarkan data yang diperoleh atas seminar nasional yang menjadi rangkaian acara dalam Mechanical Education Fair yang diselenggarakan oleh Himpunan Mahasiswa Mesin (HMM) Universitas Diponegoro, proses penyelenggaraan yang diselenggarakan oleh HMM tersebut merupakan peristiwa penyelenggaraan seminar secara langsung. Yang dimaksudkan penyelenggraan seminar secara langsung adalah seminar tersebut ditangani langsung oleh HMM tanpa menggunakan jasa perantara dari pihak ke tiga atau bisa disebut dengan jasa event organizer. HMM yang selaku penyelenggara bertugas mencari dan menghububungi pembicara untuk bekerjasama dengan pembicara untuk menjadi narasumber dalam Seminar Nasional 
dengan imbalan sesuai dengan kesepakatan. HMM selaku penyelenggara juga bertugas atas semua teknis penyelenggaraan hingga ke pemasaran dan penjualan tiket.

Berdasarkan hasil wawancara dengan M Yunandar selaku pendiri dari BeBrightEvent, saat ini terdapat dua peristiwa penyelenggaraan seminar yang dilakukan oleh BeBrightEvent sebagai berikut (1) proses yang pertama adalah saat sebuah perusahaaan atau organisasi meminta pihak BeBrightEvent untuk menyelenggarakan seminar untuk kepentingan perusahaan atau organisasi miliknya. Dalam hal ini BeBrightEvent juga bertugas untuk mencari narasumber atau pembicara untuk kegiatan tersebut. (2) proses yang kedua yaitu melalui cara kerjasama langsung dengan narasumber. Dalam hal ini, BeBrightEvent menyelenggarakan seminar atas permintaan dari narasumber. Narasumber yang ingin menyelenggarakan seminar menghubungi BeBrightEvent sebagai event organizer untuk menjadi penyelenggara. Pada peristiwa ini, pihak narasumber yang menginginkan untuk diadakan seminar tidak memberi imbalan langsung kepada BeBrightEvent, namun menggunakan sistem bagi hasil terhadap keuntungan yang diperoleh atas penyelenggaraan seminar. Sistem bagi hasil tersebut terdapat dua macam yaitu, yang pertama narasumber menetapkan jumlah berapa besar bagi hasil yang diinginkan di awal tanpa melihat seberapa besar keuntungannya dan yang kedua bagi hasil sebesar 50:50 atas keuntungan bersih yang didapat.

\section{Identifikasi BeBrightEvent dan HMM sebagai Pengusaha Kena Pajak}

Jika dilihat dalam Pasal 1 ayat (14) Undang Undang nomor 42 tahun 2009 tentang perubahan ketiga atas Undang-Undang nomor 8 tahun 1983 tentang Pajak Pertambahan Nilai dan Pajak Penjualan atas Barang Mewah, pengertian dari pengusaha adalah orang pribadi atau badan dalam bentuk apapun yang dalam kegiatan usaha atau pekerjaannya menghasilkan barang, mengimpor barang, mengekspor barang, melakukan usaha perdagangan, memanfaatkan barang tidak berwujud dari luar Daerah Pabean, melakukan usaha jasa termasuk mengekspor jasa, atau memanfaatkan jasa dari luar Daerah Pabean.

Dalam hal ini Himpunan Mahasiswa Mesin (HMM) merupakan sebuah organisasi mahasiswa yang berada di bawah Jurusan Teknik Mesin Universitas Diponegoro, sehingga HMM masih dapat dikategorikan sebagai lembaga pendidikan dan tidak termasuk dalam pengertian pengusaha. Sehingga HMM bukan merupakan Pengusaha Kena Pajak (PKP) karena tidak memenuhi syarat sebagai PKP yaitu sebagai pengusaha.

Berdasarkan dari kegiatan dan proses bisnis BeBrightEvent yang diketahui melalui hasil wawancara dan juga pengambilan data pada website, BeBrightEvent merupakan sebuah training provider dan event organizer yang menyediakan jasa penyelenggaraan di bidang seminar, pelatihan dan In House Training (IHT). Sehingga atas kegiatan tersebut memenuhi kriteria dari pengusaha seperti dalam Pasal 1 ayat (14) UU PPN tahun 1984 yaitu pengusaha adalah orang pribadi atau badan dalam bentuk apapun yang dalam kegiatan usaha atau pekerjaannya menghasilkan barang, mengimpor barang, mengekspor barang, melakukan usaha perdagangan, memanfaatkan barang tidak berwujud dari luar Daerah Pabean, melakukan usaha jasa termasuk mengekspor jasa, atau memanfaatkan jasa dari luar Daerah Pabean.

Namun dalam hal ini, BeBrightEvent bukan merupakan Pengusaha Kena Pajak. Hal ini dapat dibuktikan berdasarkan hasil wawancara dengan $M$ Yunandar selaku pendiri dan pengelola dari BeBrightEvent. Hingga saat wawancara dilakukan, BeBrightEvent masih berupa usaha bersama yang belum berbentuk sebagai badan hukum dan belum dikukuhkan menjadi Pengusaha Kena Pajak. BeBrightEvent sendiri juga belum memenuhi persyaratan untuk wajib dikukuhkan sebagai Pengusaha Kena Pajak karena memiliki peredaran bruto dalan satu tahun kurang dari Rp.4.800.000.000,00.

\section{Pengenaan Pajak Pertambahan Nilai atas seminar}

Dalam kenyataannya, HMM bukanlan sebuah Pengusaha Kena Pajak sehingga tidak dapat memungut, menyetor, melaporkan Pajak Pertambahan Nilai. Namun jika dalam hal 
HMM merupakan Pengusaha Kena Pajak sehingga dapat melakukan pemungutan PPN, maka pengenaan Pajak Pertambahan Nilai atas penyelenggaraan seminar tersebut dapat seperti hal berikut dalam perolehan pendapatan, HMM selaku penyelenggara mendapatkan penghasilan dari penjualan tiket kepada peserta seminar, sedangkan pihak pembicara seminar mendapatkan imbalan dari HMM selaku penyelenggara seminar. Maka disini HMM hanya memberikan jasa pengelolaan atau penyelenggaraan, sedangkan pihak yang memberikan jasa pendidikan adalah pihak pembicara seminar tersebut. Sehingga atas seminar tersebut, jasa penyelenggaraan yang dilakukan oleh HMM merupakan Jasa Kena Pajak, sedangkan biaya imbalan yang dikeluarkan untuk pembicara merupakan Jasa Pendidikan dan tidak termasuk dalam Jasa Kena Pajak. Sehingga dari hal tersebut DPP dari seminar yang diselenggarakan oleh HMM sebesar biaya penggantian tiket yang dikeluarkan oleh peserta seminar dikurangi biaya yang dikeluarkan pihak HMM untuk imbalan kepada pembicara seminar yang diproporsionalkan. Namun karena penjualan tiket tidak memuat daftar biaya yang dikeluarkan oleh pihak penyelenggara, maka DPP PPN atas seminar tersebut sebesar biaya penggantian tiket oleh peserta seminar sebesar Rp50.000,00 untuk umum dan Rp.45.000,00 untuk mahasiwa.

Pajak Pertambahan Nilai atas seminar yang diselenggarakan oleh HMM yang dihitung menggunaan tarif sesuai dengan Pasal 7 ayat (1) UU PPN tahun 1984 sebesar 10\% dan dikalikan dengan DPP PPN sehingga terdapat potensi PPN sebesar Rp.5.000,00 atas penjualan setiap tiket kepada umum dan potensi PPN sebesar Rp.4.500,00 untuk setiap penjualan tiket kepada mahasiswa.

Dalam hasil wawancara yang diperoleh, Muammad Yunandar selaku direktur dan pendiri dari BeBrightEvent mengaku tidak mengetahui kalau proses penyelenggaraan seminar yang dilakukan oleh BeBrightEvent tersebut merupakan penyelenggaraan jasa yang kena PPN. Namun, BeBrightEvent sendiri berencana untuk mengubah statusnya menjadi PT dan mengajukan untuk menjadi PKP pada akhir tahun 2018 ini. Sehingga, jika BeBrightEvent sudah menjadi PKP maka proses administrasi PPN tersebut dapat dilakukan. Dengan pengenaan Dasar Pengenaan Pajak (DPP) PPN tersebut berbeda tergantung proses penyelenggaraan seminar seperti apa yang dilakukan seperti dua proses penyerahan yang telah diuraikan diatas.

DPP PPN dapat dibedakan menjadi seperti hal berikut (1) Proses yang pertama adalah saat sebuah perusahaaan atau organisasi meminta pihak BeBrightEvent untuk menyelenggarakan seminar untuk kepentingan perusahaan atau organisasi miliknya. Dalam hal ini BeBrightEvent juga bertugas untuk mencari narasumber pada kegiatan tersebut, sehingga DPP PPN atas proses penyelenggaraan seminar tersebut adalah sebesar jumlah biaya penggantian atau biaya tagihan yang diberikan oleh BeBrightEvent kepada perusahaan atau organisasi yang meminta untuk diselenggarakan seminar. Dalam hal ini diambil contoh jika jumlah biaya tagihan yang diberikan oleh BeBrightEvent sebesar Rp.50.000.000,00 maka DPP PPN adalah sebesar Rp.50.000.000,00. Potensi PPN atas penyelenggaraan seminar oleh BeBrightEvent adalah sebesar tarif sesuai dengan Pasal 7 ayat (1) UU PPN tahun 1984 dikalikan dengan DPP PPN, sehingga potensi PPN sebesar 10\% x Rp.50.000.000,00 = Rp.5.000.000,00. (2) Proses yang kedua yaitu melalui cara kerjasama langsung dengan narasumber. Dalam hal ini, BeBrightEvent menyelenggarakan seminar atas permintaan dari narasumber dan menggunakan sistem bagi hasil dengan narasumber. DPP PPN atas penyelenggaraan seminar tersebut sebesar biaya penggantian atas jasa seminar yang dikeluarkan oleh peserta seminar. Dalam hal ini diambil contoh jika biaya penggantian atas tiket seminar sebesar Rp.500.000,00 sehingga DPP PPN adalah sebesar Rp.500.000,00. Potensi PPN atas penyelenggaraan seminar oleh BeBrightEvent adalah sebesar tarif sesuai dengan Pasal 7 ayat (1) UU PPN tahun 1984 dikalikan dengan DPP PPN, sehingga terdapat potensi PPN sebesar $10 \%$ x Rp.500.000,00 = Rp.50.000,00 untuk setiap peserta. 


\section{PENUTUP}

Penyerahan jasa yang masuk ke dalam pengertian dari jasa pendidikan seperti yang dimaksud dalam Pasal 4A ayat (3) huruf g UU PPN adalah jasa penyelenggaraan pendidikan sekolah dan jasa penyelenggaraan pendidikan luar sekolah. Jasa penyelenggaraan pendidikan sekolah merupakan bentuk jasa penyelenggaraan atas bentuk pendidikan formal atau resmi. Pendidikan formal merupakan bentuk pendidikan berjenjang di bawah pengawasan Kementrian Pendidikan dan Kebudayaan. Sedangkan jasa penyelenggaraan pendidikan luar sekolah merupakan jasa atas penyelenggaraan pendidikan nonformal. Pendidikan nonformal merupakan pendidikan yang dilaksanakan di luar pendidikan formal. Pendidikan nonformal dapat diselenggarakan secara fleksibel tanpa ada aturan baku yang mengikat.

Jasa atas penyelenggaraan seminar bukanlah jasa yang masuk dalam kelompok jasa pendidikan, melainkan jasa yang termasuk kedalam kelompok jasa perusahaan dan perdagangan yang berupa jasa pengelolaan. Namun, jasa atas penyelenggaraan seminar tersebut dapat masuk ke dalam kelompok dari jasa pendidikan apabila penyelenggaraan seminar tersebut diselenggarakan oleh lembaga pendidikan baik milik pemerintah maupun swasta selama masih dalam disiplin ilmu/pendidikan yang dikelolanya.

Seminar yang diselenggarakan oleh lembaga pendidikan dapat pula dikenai PPN apabila pihak penyelenggara seminar dan pembicara seminar atau narasumber merupakan pihak yang berbeda. Hal ini dikarenakan pihak yang sebenarnya memberikan jasa pendidikan merupakan pihak narasumber, sedangkan pihak penyelenggara hanya melakukan pengeolaan atas penyelenggaraan seminar tersebut.

DPP PPN atas jasa penyelenggaraan seminar adalah sebesar nilai penggantian yang dikeluarkan untuk memperoleh jasa tersebut. Nilai penggantian dapat berupa nilai tagihan yang diberikan oleh event organizer kepada klien jika menggunakan jasa event organizer atau nilai penggantian yang dikeluarkan peserta seminar untuk mengikuti seminar tersebut. DPP PPN atas jasa penyelenggaraan seminar yang diselenggarakan oleh lembaga pendidikan namun bukan berasal dari pihak yang sama dengan pembicara atau narasumber adalah sebesar nilai penggantian untuk memperoleh jasa tersebut.

\section{DAFTAR PUSTAKA}

Ahmadi, Rusland. (1988). Panduan Pengajar Buku Keterampilan Menulis. Jakarta: PPLPTK Azizah, W. N., \& Wijaya, S. (2020). Overview Of Income Tax on More VAT Differences in Retail Used Motorcycle Retail. Dinasti International Journal of Economics, Finance \& Accounting, 1(1), 134-145.

Dewantara, Ki Hajar. (1994). Bagian I Pendidikan. Yogyakarta: Luhur Taman Siswa.

Joesoef, Soelaman. (1992). Konsep Dasar Pendidikan non formal. Jakarta: Bumi Aksara.

Kesrul, M. (2004). Panduan PraktisPramuwisata Profesional. Jogjakarta. Graha Ilmu.

Lupiyaodi, Rambat dan A. Hamdani. (2011). Manajemen Pemasaran Jasa. Jakarta Selatan:

Salemba Empat.

Pendit, Nyoman S. (1999). Wisata Konvensi. Jakarta : Gramedia Pustaka Utama.

Pratiwi, T. P. (2014). Strategi Peningkatan Pendapatan Asli Daerah, Investasi Dan Pertumbuhan Ekonomi Kota Semarang Melalui Mice (Meeting, Incentive, Convention Dan Exhibition). Economics Development Analysis Journal, 3(1).

Purnomo, Yosep. (2011). Bahan Ajar Pajak Pertambahan Nilai. Tangerang Selatan: Sekolan Tinggi Akuntansi Negara.

Sukardji, Untung. (2015). Pajak Pertambahan Nilai. Edisi Revisi 2015. Jakarta: Rajawali Pers. Tenia, Hilda. (2017). Pengertian Seminar - Ciri, Tujuan Manfaat, dan Pihak-Pihak yang Terlibat Dalam seminar. https://www.kata.co.id/Pengertian/Seminar/1033. 


\section{EDUCORETAX}

Volume 1 No. 2, Juni 2021

Wijaya, S., \& Mahatma, E. A. (2017). Analisa Upaya Peningkatan Penerimaan Perpajakan dari Penggalian Potensi Pajak Atas Penghasilan Youtuber. Jurnal Manajemen Keuangan Publik, 1(2), 125-130.

Wijaya, S., \& Nirvana, A. P. (2021). Pajak Pertambahan Nilai Perdagangan Melalui Sistem Elektronik (Studi Kasus PT Shopee Internasional Indonesia). Bilancia: Jurnal Ilmiah Akuntansi, 5(3), 245-256.

Wijaya, S., \& Sabina, D. I. A. (2021). Reformulasi Pengkreditan Pajak Masukan Pasca Omnibus Law. Jurnal Pajak Indonesia (Indonesian Tax Review), 5(1). 